\title{
Gender Differences in HIV-Related Sexual Behavior among College Students from Spain and Portugal
}

\author{
Alicia Muñoz-Silva', Manuel Sánchez-García ${ }^{1}$, Ana Martins², \\ and Cristina Nunes ${ }^{2}$ \\ ${ }^{1}$ Universidad de Huelva (Spain) \\ ${ }^{2}$ Universidade do Algarve (Portugal)
}

\begin{abstract}
Under the perspective of the Theory of Planned Behavior, the objective of this study was to know the gender differences in the variables involved in the use of effective preventive measures in sexual relations against HIV in a sample of university students from Spain and Portugal. Furthermore, it is examined whether these factors produce different predictions concerning the adoption of safe sexual behaviour for young man and women in each country. The sample consisted of 683 university students, 319 Portuguese ( $64 \%$ female and $36 \%$ male) from the University of Algarve and 364 Spanish students (51\% female and 49\% male) from the University of Huelva. Data were obtained by means of a questionnaire. The data revealed that there are gender differences which apply in both countries, highlighting that the young women have more positive attitudes, greater perceived behavioural control and intention of condom use than young men. However, they protect themselves less that their male counterparts: the percentage of females who say using condoms as a contraceptive method is less than the percentage of males, and especially with their steady partners. The results are discussed in relation to gender role norms, to have a steady partner or not, gender relations, the associated meaning to sexual relations for men and women and their implications for the design of sexual educational programmes for them.

Keywords: HIV/AIDS; gender differences; university students; preventive sexual behaviors.
\end{abstract}

Bajo el enfoque de la Teoría de la Conducta Planeada, el objetivo de este estudio fue analizar las diferencias de género en cuanto a las variables que están implicadas en el uso efectivo de medidas preventivas en las relaciones sexuales frente al $\mathrm{VIH}$, en una muestra de estudiantes universitarios de España y Portugal. Además, se analizó si estas variables provocan diferencias en las predicciones relacionadas con la adopción de conductas sexuales seguras por chicos y chicas en cada país. La muestra estaba formada por 683 estudiantes universitarios, 319 portugueses (64\% mujeres y $36 \%$ hombres) de la Universidade do Algarve y 364 estudiantes españoles ( $51 \%$ mujeres y $49 \%$ hombres) de la Universidad de Huelva. Los datos fueron recogidos a través de un cuestionario. Los datos revelaron que hay diferencias de género que se mantienen en ambos países, destacando que las chicas tienen actitudes más positivas, una mayor percepción de control del comportamiento y una mayor intención de uso del preservativo que los chicos. Sin embargo, las chicas se protegen menos que sus homólogos masculinos: el porcentaje de mujeres que dicen usar el preservativo como un método anticonceptivo es menor que el porcentaje de hombres, y especialmente con sus parejas estables. Los resultados se discuten en relación con el papel de las normas de género, con el hecho de tener pareja estable o no, las relaciones de género, el significado asociado a las relaciones sexuales entre hombres y mujeres y sus implicaciones para el diseño de programas de educación sexual.

Palabras clave: VIH/SIDA; diferencias de género; estudiantes universitarios; conductas sexuales de prevención.

We would like to thank the anonymous reviewers for comments and suggestions which improved the quality of this paper.

Correspondence concerning this article should be addressed to Alicia Muñoz-Silva. Departamento de Psicología Evolutiva y de la Educación. Facultad de Ciencias de la Educación. Universidad de Huelva. Campus de El Carmen, s/n. 21007 Huelva (Spain). Phone: +34-959219208; Fax: +34-959219357. E-mail: amsilva@uhu.es 
HIV affects mainly to young people. So, among adults 15 years and older, young people (15 to 24 years of age) accounted for $40 \%$ of new HIV infections in 2006 (UNAIDS \& WHO, 2006). Intravenous drug users sharing needles or unprotected same-sex relations still constitute an important means for HIV transmission. However, in Western Europe the number of HIV infections newly diagnosed in persons infected through heterosexual contact increased from 6017 in 2001 to 10722 in 2006 (EuroHIV, 2006, 2007), with the corresponding increase in the number of infected women. Furthermore, the proportion of women among newly infected people with a diagnosis of HIV infection increased from $25 \%$ in 1997 to $38 \%$ in 2002 (UNAIDS, 2004) and, more recently, the $35 \%$ of newly diagnosed HIV infections in 2006 were female (EuroHIV, 2007). Similarly, in USA, the AIDS epidemic has varied significantly over the last decade. It has been estimated that during this period, 40,000 people have been infected with HIV each year, although the epidemic is now affecting Afro-Americans disproportionately and a growing number of women: from $15 \%$ before 1995 to $27 \%$ in 2004 (UNAIDS \& WHO, 2004, 2006).

In the European context, both Spain and Portugal have high rates of HIV/AIDS. So, whereas the average in Western and Central Europe for the people aged 15 to 49 was $0.3 \%$ (UNAIDS \& WHO 2005), the prevalence rates in 2005 in Spain were $0.6 \%$ and of $0.4 \%$ in Portugal (UNAIDS, 2006). An important difference between these two countries is the primary exposure categories in each country. So, in 2005, the heterosexual transmission was the most frequent means for HIV transmission in Portugal (47.7\% of cases), followed by intravenous drug users $(40.9 \%)$ and same-sex and bisexual behavior (8.6\%) (Ministério da Saude \& Instituto Nacional de Saúde Dr. Ricardo Jorge. Centro de Vigilância Epidemiológica das Doenças Transmissíveis, 2006). In Spain, the first means of transmision was the use of intravenous drug (47.8\%), followed by the heterosexual contact $(30.5 \%)$ and same-sex and bisexual behavior (15.4\%) (Instituto de Salud Carlos III \& Ministerio de Sanidad y Consumo. Vigilancia Epidemiológica del SIDA en España, 2005). These differences may be due to the different preventive programmes of each country. In Portugal, the first years the main focus were intravenous drug users, later they developed the first sex education school programmes in 2001, and finally, in 2003, they carried out prevention programmes aimed at young people sexuality (Coordenação Nacional para a Infecção VIH/SIDA, 2006). The 'Plano Nacional de Luta Contra a Sida 2004-2006' admits these gaps and emphasises the need to tackle the gender differences and the weakness of women against HIV/AIDS (Comissão Nacional Luta Contra a Sida, 2004). In contrast, the first strategic plan against AIDS developed by the Spanish Ministry of Health and Consumption, besides pointing out the necessity of specific preventive programmes aimed to women, shows the longer Spanish trajectory in preventive programmes and measures aimed to children, adolescents and young people, that are considered a priority focus as regards prevention. The first national campaign for preventing HIV/AIDS and other sexually transmitted diseases among high school and university students was developed in the academic year 1995/1996 (Secretaría del Plan nacional sobre el SIDA del Ministerio de Sanidad y Consumo, 1997).

On the other hand, the existence of gender differences in sexual behavior has been made clear in numerous studies. Research has demonstrated that young men and women have different patterns of risk behavior related to sexual transmission of AIDS and other sexually transmitted diseases (STDs): young men have more sexual partners (Babikian et al., 2004; Hynie, Lydon, Côté \& Wiener, 1998; Kotchick, Shaffer, Forehand \& Miller, 2001; Merakou, Costopoulos, Marcopoulou \& Kourea-Kremastinou, 2002; Murphy, Rotheram-Borus \& Reid, 1998; Newman \& Zimmermann, 2000; Siegel, Klein \& Roghmann, 1999; Wendt \& Solomon $1995)$ while young women use the condom less frequently in their sexual relations (Babikian et al., 2004; Baele, Dusseldorp \& Maes, 2001; Bazargan, Kelly, Stein, Husaini \& Bazargan, 2000; Gebhardt, Kuyper \& Greunsven, 2003; Kotchick et al., 2001; Laraque, Maclean, Brown-Peterside, Ashton \& Diamond, 1997; Merakou et al., 2002; Murphy et al., 1998; Newman \& Zimmermann, 2000; Wendt \& Solomon 1995). Thus, young women seem more inclined to adopt the 'monogamy' preventive strategy, that is characterised by having fewer partners but not using condoms consistently (Newman \& Zimmermann, 2000). But these young women may be at long-term cumulative risk as the norm among youth is serial monogamy (Bayés, Pastells \& Tuldra, 1995; Seidman \& Rieder, 1994).

Moreover, women are more vulnerable to becoming infected with AIDS. There are a variety of reasons for this, such as unequal educational or medical opportunities for boys and girls and the discrimination or violence against women, more relevant in less developed countries and marginalised women (Amaro, Raj \& Reed, 2001; Cummings, Mengistu, Negash, Bekele \& Ghile, 2006; UNAIDS, 2004).

Given that condom use is the main means against HIV, from a protection approach is basic to analyse the variables associated with its use. There are various factors related to condom use among young adults. Different studies highlight the role of attitudes, subjective social norms and perceived behavioral control as important variables explaining condom use intention and behavior. These factors are used together in the Ajzen's Theory of Planned Behavior (Ajzen, 1985) and in several studies that use these variables to explain the adoption of preventive measures in sexual relations (Fazecas, Senn \& Ledgerwood, 2001; Gebhardt et al., 2003). These variables have also been used separately in several studies that have drawn on this and other theoretical frameworks, highlighting the role of attitudes towards 
condom use (Bazargan et al., 2000; Bosompra, 2001; Parsons, Halkitis, Bimbi \& Borkowski, 2000; Rosenstock, Strecher \& Becker, 1994) subjective social norms or social pressure from the environment and people that are important to the subject (Bosompra, 2001; Laraque et al., 1997; Murphy et al., 1998), and perceived behavioral control, either in the form of skills for buying, taking or putting the condom on correctly (Baele et al., 2001), behavioral skills in negotiating and ensuring condom use with the partner (Baele et al., 2001; Basen-Engquist et al., 1999; Bazargan et al., 2000; Gutiérrez, Oh \& Gillmore, 2000; Holscheneider \& Alexander, 2003; Parsons et al., 2000) or that guarantee its use even in difficult situations as may be the case of being sexually excited or under the effect of drugs (Baele et al., 2001; Bazargan et al., 2000; Parsons et al., 2000).

Under the perspective of the Theory of Planned Behavior, the present paper aims to measure gender differences in the variables -attitudes, social norm, perceived behavioral control, intention of condom use- involved in the use of effective preventive measures against AIDS, and specifically in the condom use, and whether these differences are upheld in a sample of university students from Spain and Portugal. Furthermore, we wish to analyse whether these variables produce different predictions concerning the adoption of safe sexual behavior for young men and women in each country. We study the condom use as preventive measure against AIDS, therefore we ask about its use even when other contraceptive methods are used. We are also interested in detailing if the subjects use contraceptive methods different to the condom, how these methods are related to whether or not there is a steady partner, and the number of sexual partners in the past year given that they are other important indicators of the safe or unsafe sexual behavior of young adults.

\section{Methods}

\section{Participants}

The sample consisted of 683 university students, 319 Portuguese (64\% female and 36\% male) from the University of Algarve and 364 Spanish students (51\% female and 49\% male) from the University of Huelva. The average age of the Portuguese students was $22.34(S D=4.2$; median $=$ 21) while for their Spanish counterparts it was 20.94 (SD $=3.5$; median $=20)$. In both countries a high percentage of students had had sexual relations $(87.6 \%$ for Spanish students and $86 \%$ for Portuguese students).

\section{Measures}

The variables were measured with a questionnaire (two versions: Portuguese and Spanish) drawn up by researchers, from a revision of different studies (Basen-Engquist et al.,
1999; Krahé \& Reiss 1995; Oliva, Serra \& Vallejo, 1993; Reinecke, Schmidt \& Ajzen, 1996; Sánchez-García, 2001) to analyse preventive behavior against the transmission of the AIDS virus in young adults. The response options (except for the attitude, for which a differential semantic scale was used) was an 7-point scale: From 1 (strongly disagree) to 7 (strongly agree). All items covered include the expression "even if we use another contraceptive method." This expression does not appear on the tables to avoid repetition. All the items in the questionnaire (see Table 1) were recoded so that a higher score meant a more positive attitude towards condom use, a social norm more in favour of its use, greater perceived behavioral control or greater intention of use. Besides the scores in each of the items, we calculated an index for each variable resulting from the mean of the items within it.

The attitudes towards condom use were assessed using 16 items $(\alpha=.82)$. For items 1 to 7 the students expressed their level of agreement (from 1 - totally disagree, to 7 - totally agree-) with a series of statements. In the remaining items, students replied to a bipolar 7-point item based on a semantic difference. For example: 'Using the condom in my sexual relations, even if we use another contraceptive method, is (or would be) very exciting / not at all exciting'.

The perceived social norm was assessed using 6 items ( $\alpha=.75$ ), measuring the opinion that participants felt that their parents, friends and partner had about condom use and whether they thought that these people would recommend its use or not.

The perceived behavioral control was assessed using 8 items $(\alpha=.73)$. Within perceived behavioral control we distinguished among different aspects: negotiation skills, ability to ensure its use in especially complicated situations such as under the effects of alcohol, drugs or in a state of great excitation, and practical aspects. The condom use intention was measured using three items $(\alpha=.61)$.

The sexual behavior of the subjects was analysed through the frequency of condom use, the number of sexual partners that they had had in the previous year and the contraceptive methods they used. The frequency of condom use was measured using a single item: 'In general, in your sexual relations and although you may use another contraceptive method, how often do you use a condom?' They responded to this on a scale from 1 -never- to 7 -always-. The number of sexual partners was assessed through a question in which subjects had to say how many sexual partners they had had in the past twelve months. The possible replies were 'none', 'from 1 to 2 ', 'from 3 to 5 ' or 'more than 5 '. The question about the type of contraceptive methods the participant used had the following options: 'Pill', 'Condom', 'Condom and another. Which?', 'Other. Which?', 'None. Why don't you use them?' The question about to have steady partner had two options: 'At the moment, do you have steady partner? (Yes/No)'. 


\section{Procedure}

This investigation used a correlational and transversal design. The data were obtained from individual questionnaires administered to the students in their classrooms in the second semester of 2005/06 academic year. Researchers contacted university lecturers from different subjects - 20 subjects in 14 different courses from two public universities of Portugal and Spain - and asked them permission to explain the study and hand out the questionnaires to their students. The participants were appropriately informed the thematic of the survey, they were explained about the voluntary character of this and they were assured the anonymity and confidentiality of their answers. Finally, they were asked if they had understood these instructions and they were communicated that their negative to participate would never imply negative consequences for them. No student refused to answer the questionnaire. They did this at the end of their classes, and students then filled them and left them on their desks. They took on average 20 minutes to fill in the questionnaire.

\section{Statistical Analysis}

Given the nature of our correlational study we used different statistical tests to analyse the relationship between the measured variables. To test differences by gender in the items responses we used Student's t-tests. Analysis of chisquare was used to verify the relation between contraceptive methods and gender, and another hand, contraceptive methods and to have (or not) a steady partner. To test whether differences in gender exist within each country in the behavior of these combined variables predicting condom use intention and behavior, we conducted two forced entry multiple lineal regression analysis. All statistical tests were two-tailed and a P-value $<.05$ was considered statistically significant. For all the statistical analyses, SPSS (11.1) was used

\section{Results}

As we can see in Table 1, there are differences in gender which apply in both countries. Both in Spain and Portugal, women have more favourable attitudes towards the condom use, even if they use another complementary contraceptive method, and they perceive less costs than the men (using the condom interrupts sexual foreplay, makes the partner feel mistrust or carrying them with you makes the partner feel that you're only interested in the sex). The young women from each country see its use as more romantic and comfortable. The Spanish women also perceive to a lesser degree than the men from Spain that the external aspects of the condom are disagreeable and see its use as being easier, safer, more useful and a better idea than the Spanish men. In turn, the Portuguese women perceive the condom as being more agreeable than their male compatriots and its use gives them more peace of mind than it does to the men.

No differences in gender are observed in the perceived social norm, both in general terms and in the social pressure that subjects perceive from the different people making up their most significant social contexts: parents, friends and partner.

In relation to perceived behavioral control, we see the same pattern in both countries: the young women perceive greater skills for negotiating with the partner to use the condom, and also greater capacity to ensure its use in especially complicated situations, while the men perceive greater control for practical or logistical aspects.

Thus in relation to behavioral skills in negotiating and ensuring condom use with the partner, both the Portuguese and Spanish women think to a greater extent than their male compatriots that, even if they were to use another contraceptive method, they would not give in if their partner wanted to have sexual relations without a condom. Furthermore, the Spanish women think that if they want to use the condom they would be able to convince their partner to use it. In the case of condom use in difficult situations, the women from both countries are more convinced than the men that they would be capable of using the condom even if they were under the influence of alcohol or drugs or were highly excited, even on the point of losing control. The men, on the other hand, feel themselves more capable of going to buy them, putting them on correctly or explaining this to their partner.

The Spanish and Portuguese women also differ from the men from their respective countries in that they show greater intention of condom use when having relations with a person they knew, even if they used another contraceptive method. Spanish women also have a greater intention of using the condom than the men when having sexual relations with a person that they knew was promiscuous.

No differences are found between men and women from the two countries in the frequency of condom use, as in both cases they refer to a fairly high frequency of use, especially in Spain.

To test whether differences in gender exist within each country in the behavior of these combined variables predicting condom use intention and behavior, we conducted two forced entry multiple lineal regression analysis (see Table 2). In the first model, we analysed the prediction of the intention of use from the attitudes, perceived social norms and different variables referring to self-efficacy or perceived behavioral control. The results indicate that in both countries, for both young women and men, although more for the latter, the variables attitude, perceived social norms and negotiation skills manage to explain a high percentage of condom use intention. The sole difference between the countries is that for Spanish men, perceived self-efficacy in difficult situations also contributes to explaining intention of use. 
Table 1

Mean (and standard deviations) of the variables. Comparison according to gender in each country (t-test)

\begin{tabular}{|c|c|c|c|c|}
\hline & \multicolumn{2}{|c|}{ Portugal } & \multicolumn{2}{|c|}{ Spain } \\
\hline & Female & Male & Female & Male \\
\hline 1. ATTITUDES & $5.41(0.77)$ & $5.07(0.83)^{* * *}$ & $5.31(0.68)$ & $4.87(0.79)^{* * *}$ \\
\hline 1.1. A young man/woman of my age should always use one & $6.25(1.20)$ & $6.17(1.32)$ & $5.91(1.46)$ & $5.58(1.72)$ \\
\hline 1.2. It interrupts sexual foreplay & $5.60(1.68)$ & $4.91(1.84)^{* *}$ & $5.11(1.87)$ & $4.24(1.94)^{* * *}$ \\
\hline 1.3. Makes the partner feel mistrust & $6.28(1.40)$ & $5.90(1.55)^{*}$ & $6.52(1.14)$ & $6.02(1.60)^{* *}$ \\
\hline 1.4. May make the partner feel that your are only interested in the sex & $6.36(1.23)$ & $5.76(1.57)^{* * *}$ & $6.42(1.24)$ & $5.64(1.76)^{* * *}$ \\
\hline 1.5. Disagreeable external aspects & $4.70(1.71)$ & $4.41(1.76)$ & $4.81(1.87)$ & $4.22(1.72)^{* *}$ \\
\hline 1.6. They are easy to use & $5.92(1.27)$ & $5.77(1.34)$ & $6.28(1.15)$ & $5.82(1.43)^{* *}$ \\
\hline 1.7. I am in favour of condom use & $5.84(1.60)$ & $5.56(1.80)$ & $5.56(1.87)$ & $5.00(2.10)^{* *}$ \\
\hline 1.8. It's exciting & $3.57(1.43)$ & $3.29(1.54)$ & $3.10(1.41)$ & $3.07(1.50)$ \\
\hline 1.9. It's safe & $6.77(0.75)$ & $6.57(1.00)$ & $6.72(0.78)$ & $6.38(1.15)^{* *}$ \\
\hline 1.10. It's agreeable & $3.90(1.45)$ & $3.50(1.45)^{*}$ & $3.77(1.27)$ & $3.66(1.41)$ \\
\hline 1.11. It's boring & $4.07(1.49)$ & $3.76(1.42)$ & $3.90(1.33)$ & $3.66(1.34)$ \\
\hline 1.12. It's useful & $6.64(1.01)$ & $6.46(1.02)$ & $6.38(1.40)$ & $5.90(1.71)^{* *}$ \\
\hline 1.13. It's romantic & $3.65(1.41)$ & $3.27(1.67)^{*}$ & $3.43(1.43)$ & $3.07(1.55)^{*}$ \\
\hline 1.14. It gives peace of mind & $5.89(1.59)$ & $5.50(1.62)^{*}$ & $6.11(1.47)$ & $5.95(1.38)$ \\
\hline 1.15. It's comfortable & $4.16(1.73)$ & $3.59(1.66)^{* *}$ & $3.83(1.80)$ & $3.33(1.72)^{* *}$ \\
\hline 1.16. It's a good idea & $6.66(1.01)$ & $6.64(1.38)$ & $6.70(0.80)$ & $6.44(1.34)^{*}$ \\
\hline 2. PERCEIVED SOCIAL NORM & $5.63(1.02)$ & $5.61(1.00)$ & $5.30(1.26)$ & $5.26(1.14)$ \\
\hline 2.1. My friends think you should use one & $5.31(1.51)$ & $5.32(1.45)$ & $4.87(1.90)$ & $4.92(1.73)$ \\
\hline 2.2. My friends would say I should use one & $5.52(1.46)$ & $5.48(1.57)$ & $5.08(1.80)$ & $4.78(1.77)$ \\
\hline 2.3. My parents think you should use one & $6.28(1.11)$ & $6.31(1.10)$ & $6.29(1.39)$ & $6.05(1.49)$ \\
\hline 2.4. My parents would say I should use one & $6.27(1.23)$ & $6.32(1.13)$ & $5.99(1.74)$ & $5.92(1.67)$ \\
\hline 2.5. My partner thinks you should use one & $5.31(1.64)$ & $5.41(1.63)$ & $5.02(1.95)$ & $5.20(1.85)$ \\
\hline $\begin{array}{l}\text { 2.6. If we use another contraceptive, my partner doesn't like me } \\
\text { proposing the use of a condom }\end{array}$ & $5.08(2.00)$ & $4.96(1.85)$ & $4.54(2.24)$ & $4.63(2.01)$ \\
\hline \multicolumn{5}{|l|}{ 3. PERCEIVED BEHAVIORAL CONTROL } \\
\hline 3.1. Negotiation skills & $5.78(1.19)$ & $5.42(1.14)^{* *}$ & $5.38(1.40)$ & $4.84(1.29)^{* * *}$ \\
\hline 3.1.1. I would be able to convince my partner to use it & $6.48(0.84)$ & $6.35(0.91)$ & $6.16(1.35)$ & $5.81(1.25)^{*}$ \\
\hline 3.1.2. I would not give in if my partner did not want to use it & $5.08(1.92)$ & $4.49(2.01)^{*}$ & $4.60(2.16)$ & $3.87(2.01)^{* *}$ \\
\hline 3.2. Control in difficult situations & $6.01(1.11)$ & $5.54(1.32)^{* *}$ & $5.52(1.58)$ & $5.01(1.69)^{* *}$ \\
\hline $\begin{array}{l}\text { 3.2.1. I would be able to use it even if I was under the influence } \\
\text { of alcohol }\end{array}$ & $6.08(1.20)$ & $5.75(1.32)^{*}$ & $5.79(1.67)$ & $5.17(1.82)^{* *}$ \\
\hline $\begin{array}{l}\text { 3.2.2. I would be able to use it even if I was under the influence } \\
\text { of drugs }\end{array}$ & $5.91(1.40)$ & $5.39(1.70)^{* *}$ & $5.43(1.75)$ & $4.88(1.92)^{* *}$ \\
\hline 3.2.3. I would be able to use it even if I was very excited & $6.03(1.33)$ & $5.46(1.68)^{* *}$ & $5.34(1.89)$ & $4.89(1.97)^{*}$ \\
\hline 3.3. Practical aspects & $6.28(0.94)$ & $6.54(0.71)^{* *}$ & $6.07(1.16)$ & $6.42(0.79)^{* *}$ \\
\hline $\begin{array}{l}\text { 3.3.1. I would be able to put it on correctly or explain how to do } \\
\text { so to my partner }\end{array}$ & $6.21(1.24)$ & $6.53(0.88)^{* *}$ & $6.02(1.32)$ & $6.40(0.97)^{* *}$ \\
\hline 3.3.2. I could buy them & $6.04(1.41)$ & $6.46(1.22)^{* *}$ & $6.05(1.63)$ & $6.52(1.02)^{* *}$ \\
\hline 3.3.3. I would be able to carry them on me, just in case & $6.60(0.79)$ & $6.64(0.75)$ & $6.14(1.45)$ & $6.34(1.10)$ \\
\hline 4. CONDOM USE INTENTION & $5.98(1.08)$ & $5.71(1.19)^{*}$ & $5.57(1.27)$ & $5.13(1.34)^{* *}$ \\
\hline $\begin{array}{l}\text { 4.1. If I have relations with someone I know and we use another } \\
\text { contraceptive, I would not use a condom }\end{array}$ & $5.43(1.86)$ & $4.92(1.97)^{*}$ & $4.85(2.10)$ & $4.17(2.10)^{* *}$ \\
\hline $\begin{array}{l}\text { 4.2. If I have relations with someone who has had many partners, } \\
\text { I would always use one even if we used another contraceptive method }\end{array}$ & $6.70(1.02)$ & $6.56(1.07)$ & $6.41(1.26)$ & $6.06(1.35)^{*}$ \\
\hline 4.3. I will always try to use one & $5.80(1.55)$ & $5.64(1.63)$ & $5.46(1.65)$ & $5.14(1.78)$ \\
\hline 5. FREQUENCY OF CONDOM USE & $4.58(2.15)$ & $4.89(2.17)$ & $5.42(2.16)$ & $5.66(1.73)$ \\
\hline
\end{tabular}

$* \mathrm{p}<.05 ; * * \mathrm{p}<.01 ; * * * \mathrm{p}<.001$ 
Table 2

Summary of Regression Analysis for Variables predicting condom use intention and frequency of condom use among Portuguese and Spanish female and male

\begin{tabular}{|c|c|c|c|c|c|c|c|c|}
\hline \multicolumn{9}{|c|}{ PREDICTION OF CONDOM USE INTENTION } \\
\hline & \multicolumn{4}{|c|}{ Portugal } & \multicolumn{4}{|c|}{ Spain } \\
\hline & \multicolumn{2}{|c|}{ Female $(\mathrm{N}=203)$} & \multicolumn{2}{|c|}{ Male $(\mathrm{N}=114)$} & \multicolumn{2}{|c|}{ Female $(\mathrm{N}=183)$} & \multicolumn{2}{|c|}{ Male $(\mathrm{N}=172)$} \\
\hline & $\beta$ & $\mathrm{R}^{2}$ & $\beta$ & $\mathrm{R}^{2}$ & $\beta$ & $\mathrm{R}^{2}$ & $\beta$ & $\mathrm{R}^{2}$ \\
\hline Attitudes & $.28 * * *$ & $.23 * * *$ & $.34 * * *$ & $.46^{* * *}$ & $.20^{*}$ & $.35 * * *$ & $.35 * * *$ & $.57 * * *$ \\
\hline Social norms & $.15^{*}$ & & $.24 * *$ & & $.24 * *$ & & $.20 * *$ & \\
\hline Self-efficacy negotiation & $.19 * *$ & & $.23 * *$ & & $.24 * *$ & & $.31 * * *$ & \\
\hline Self-efficacy in difficult situations & .02 & & .10 & & .09 & & $.13^{*}$ & \\
\hline Self-efficacy, practical aspects & -.07 & & .00 & & -.09 & & -.04 & \\
\hline \multicolumn{9}{|c|}{ PREDICTION OF FREQUENCY OF CONDOM USE } \\
\hline & \multicolumn{4}{|c|}{ Portugal } & \multicolumn{4}{|c|}{ Spain } \\
\hline & \multicolumn{2}{|c|}{ Female $(\mathrm{N}=153)$} & \multicolumn{2}{|c|}{ Male $(\mathrm{N}=98)$} & \multicolumn{2}{|c|}{ Female $(\mathrm{N}=149)$} & \multicolumn{2}{|c|}{ Male $(\mathrm{N}=159)$} \\
\hline & $\beta$ & $\mathrm{R}^{2}$ & $\beta$ & $\mathrm{R}^{2}$ & $\beta$ & $\mathrm{R}^{2}$ & $\beta$ & $\mathrm{R}^{2}$ \\
\hline Intention of use & $.40 * * *$ & $.29 * * *$ & $.44 * * *$ & $.27 * * *$ & $.33 * * *$ & $.20 * * *$ & $.33 * * *$ & $.28 * * *$ \\
\hline Self-efficacy negotiation & $.22 * *$ & & .12 & & $.23^{*}$ & & .17 & \\
\hline Self-efficacy in difficult situations & -.02 & & .04 & & -.15 & & .13 & \\
\hline Self-efficacy, practical aspects & -.11 & & -.02 & & -.02 & & .01 & \\
\hline
\end{tabular}

$\mathrm{p}<.05 ; * * \mathrm{p}<.01 ; * * * \mathrm{p}<.001$.

$\beta=$ standardized regression coefficients.

$\mathrm{R}^{2}=$ proportion of explained variance of the predicted variable.

In the second model, in line with the proposals of the Theory of Planned Behavior, we aim to predict condom use behavior from the intention of use and the different aspects of self-efficacy or perceived behavioral control. In this case, the percentages explained of the behavior are fairly similar for young men and women from both countries, although there are clear gender differences in the variables explaining frequency of condom use: for the men the only explanatory variable is intention of use; while in the women this behavior is explained by the intention together with the perception of negotiation skills.

Another variable chosen to study the sexual behavior of our students was the number of sexual partners. Our data point to differences in Spain between young men and women over the number of sexual partners. A greater percentage of Spanish men say they have had ' 3 to 5 ' or 'more than $5^{\prime}$ sexual partners, while the women refer to less sexual partners in the previous year $\left(\chi^{2}=19.47\right.$; d.f. $=3 ; p<.001)$. No significant differences were found in the Portuguese sample.

The description of the contraceptive measures used by the whole sample is shown in Table 3 . These results show that the majority of the university students interviewed use contraceptive methods, mainly the condom, followed by the pill. A very low percentage of these young adults use no contraceptive method at all. The table also shows that the use of the pill on its own is much more frequent among the young women from both countries, but especially among the Portuguese, while using the condom on its own is much more frequent among the men, with its combined use with the pill being more probable amongst the women, in particular the Portuguese. We can also point to the finding that the condom use is more widespread among the Spanish students compared to the Portuguese (all referred differences are significant, with standardized residuals greater than \pm 1.96 ).

One variable that may have a bearing on the type of contraceptive method chosen is whether the student has a steady partner or not. In relation to the possible association existing in our sample between gender and having a steady partner, data indicate that in both Spain and Portugal a greater number of women say that they are in a steady relationship at the time of the interview.

Finally, we analysed the possible differences in gender in the choice of contraceptive methods between subjects with or without steady partner in each country (Table 4). Our interest lied in analysing the adoption of preventive sexual behavior not just against unwanted pregnancies but also against sexually transmitted diseases. For this reason, the responses were recoded in two categories: pill and 
Table 3

Contraceptive methods used by the Spanish and Portuguese students

\begin{tabular}{|c|c|c|c|c|}
\hline & \multicolumn{2}{|c|}{ Portugal $\left(\chi^{2}=60.55, \mathrm{p}<.001\right)$} & \multicolumn{2}{|c|}{ Spain $\left(\chi^{2}=15.24, p<.01\right)$} \\
\hline & Female & Male & Female & Male \\
\hline \multicolumn{5}{|l|}{ CONTRACEPTIVE METHOD } \\
\hline Pill & $50(29.1 \%)$ & $8(8 \%)$ & $19(12.2 \%)$ & $7(4.4 \%)$ \\
\hline Condom & $36(20.9 \%)$ & $61(61 \%)$ & $97(62.2 \%)$ & $128(80.5 \%)$ \\
\hline Condom and other (basically the pill) & $85(49.4 \%)$ & $25(25 \%)$ & $26(16.7 \%)$ & $18(11.3 \%)$ \\
\hline Other & $1(0.6 \%)$ & $2(2 \%)$ & $6(3.8 \%)$ & $4(2.5 \%)$ \\
\hline None & 0 & $5(5 \%)$ & $8(5.1 \%)$ & $2(1.3 \%)$ \\
\hline Total & 172 & 101 & 156 & 159 \\
\hline
\end{tabular}

$\mathrm{df}=4$.

Table 4

Relation between having a steady partner and contraceptive method used in each country

\begin{tabular}{|c|c|c|c|c|c|c|c|c|}
\hline & \multicolumn{4}{|c|}{ Portugal } & \multicolumn{4}{|c|}{ Spain } \\
\hline & \multicolumn{2}{|c|}{$\begin{array}{c}\text { Steady partner } \\
\left(\chi^{2}=8.96, p<.01\right)\end{array}$} & \multicolumn{2}{|c|}{$\begin{array}{c}\text { No steady partner } \\
\left(\chi^{2}=3.65, \mathrm{p}>.05\right)\end{array}$} & \multicolumn{2}{|c|}{$\begin{array}{c}\text { Steady Partner } \\
\left(\chi^{2}=5.14, p<.05\right)\end{array}$} & \multicolumn{2}{|c|}{$\begin{array}{l}\text { No steady partner } \\
\left(\chi^{2}=.199, p>.05\right)\end{array}$} \\
\hline & Female & Male & Female & Male & Female & Male & Female & Male \\
\hline \multicolumn{9}{|c|}{ CONTRACEPTIVE METHOD } \\
\hline Pill & $\begin{array}{c}44 \\
(33.3 \%)\end{array}$ & $\begin{array}{c}7 \\
(12.3 \%)\end{array}$ & $\begin{array}{c}6 \\
(15.4 \%)\end{array}$ & $\begin{array}{c}1 \\
(2.7 \%)\end{array}$ & $\begin{array}{c}18 \\
(15.5 \%)\end{array}$ & $\begin{array}{c}6 \\
(5.9 \%)\end{array}$ & $\begin{array}{c}1 \\
(3.8 \%)\end{array}$ & $\begin{array}{c}1 \\
(2.1 \%)\end{array}$ \\
\hline Condom & $\begin{array}{c}88 \\
(66.7 \%)\end{array}$ & $\begin{array}{c}50 \\
(87.7 \%)\end{array}$ & $\begin{array}{c}33 \\
(84.6 \%)\end{array}$ & $\begin{array}{c}36 \\
(97.3 \%)\end{array}$ & $\begin{array}{c}98 \\
(84.5 \%)\end{array}$ & $\begin{array}{c}96 \\
(94.1 \%)\end{array}$ & $\begin{array}{c}25 \\
(96.2 \%)\end{array}$ & $\begin{array}{c}47 \\
(97.9 \%)\end{array}$ \\
\hline
\end{tabular}

$\mathrm{df}=1$

condom. In the first option we considered the subjects that replied that they used the pill alone and in the second those that used the condom, on its own or with another contraceptive method. The results indicate that there are differences in gender that are common to both countries, but only in the group of students with a steady partner. These differences indicate that Spanish and Portuguese women with steady partner protect themselves less against sexually transmitted diseases than their male peers as they use to a greater extent the pill as the only contraceptive method.

\section{Discussion}

From the results obtained we can state that the majority of the university students interviewed in our study have healthy and safe sexual behavior, given their high frequency of condom use. On this point, our findings differ from those obtained by other researchers referring to a greater proportion of risk behavior among the university population from several countries (Bradley \& Wildman, 2002; Cok, Gray \& Ersever, 2001; Parsons et al., 2000).
However, the findings also show important gender differences in the sexual behavior. Thus, firstly, although significant differences do not exist between young men and women in the frequency of condom use, we find important discrepancies concerning their use of contraceptive methods. We found, as other authors have, that the percentage of women who say using condoms as a contraceptive method is less than the percentage of men (Babikian et al., 2004; Baele et al., 2001; Bazargan et al., 2000; Cerqueira-Santos, Koller \& Wilcox, 2008;Gebhardt et al., 2003; Laraque et al., 1997; Murphy et al., 1998; Newman \& Zimmerman, 2000; Wendt \& Solomon, 1995), while they use the contraceptive pill to a greater extent, thereby increasing their vulnerability to sexually transmitted diseases.

When analysing the responses that the students gave to the different items from the questionnaire we also found several gender differences that were common to both countries. Both Portuguese and Spanish women have more favourable attitudes towards condom use, perceiving more benefits and fewer costs in their use than their male peers. These results tie in with those obtained by other researchers 
(Campbell, Pepalu \& DeBro, 1992; Parsons et al. 2000; Sacco, Rickman, Thompson, Levine \& Reed, 1993,). In addition, they see themselves as more skilful in the negotiation of condom use with the partner and to ensure its use in particularly difficult situations, which had also been found by other researchers (Dekin, 1996; Kvalem \& Træen, 2000; Murphy et al., 1998; Parsons et al., 2000). In line with the aforementioned point, they also have a greater intention of using the condom in their sexual relations.

However, as the women from our sample use the condom as a contraceptive method on a percentage smaller than their male peers, their attitudes, perceived behavioral control or greater intention of use has not been translated into a greater frequency of condom use in sexual relations. This has also been found by several researchers that have used these variables in university population (Carrasco, MuñozSilva \& Sánchez-García, 2003; Parsons et al., 2000) and in younger adolescents (Martínez-Donate et al., 2004).

We believe that an important variable that may influence these results is the fact that in both samples more than half of the students have a steady partner, and that partner relations are more frequent among the women than among the men both in Spain and Portugal. One finding contrasted by several studies is that in these partner relations it is very common for other contraceptive methods such as the pill to be used as the main concern is the prevention of unwanted pregnancies and not the possibility of becoming infected with illnesses such as HIV (Bimbela, Jiménez, Alfaro, Gutiérrez \& March, 2002; Cerqueira-Santos et al., 2008; Gebhardt et al., 2003; Wendt \& Solomon, 1995). Thus, as some authors have suggested (Bimbela et al., 2002; Dias, Matos \& Gonçalves, 2005; Fazecas et al. 2001; Moore, Rosenthal \& Mitchell, 1996; Thorburn, Harvey \& Ryan, 2005; Woolf \& Maisto, 2008) it is possible that adolescents and young adults think that having sex without a condom within a partner relation is an indication of trust in the partner or love towards him/her, which would make it more difficult to propose its use. On this point, several authors (Gebhardt et al., 2003; Hynie et al., 1998; Lameiras, Nuñez, Rodríguez, Bretón y Agudelo, 2005; Manuel, 2005) have found that for men and women the condom use is associated more with casual encounters than with steady partner relations, which may make subjects unwilling to propose its use when they hope that the relationship will have some continuity. But the study by Gebhardt et al.(2003) also states that although young men and women protect themselves less in their encounters with their steady partners than in their more sporadic relations, the women are always the ones who protect themselves less, and especially with their steady partners. We obtained the same result in our sample: within the group of subjects with steady partners, the women use the pill more than the men, who in turn use the condom to a greater extent. Thus the young women in our study seem to be using the preventive strategy labelled serial monogamy to a greater extent. However, we coincide with several authors (Bazargan et al., 2000; Fazecas et al., 2001; Newman \& Zimmerman, 2000) who point out that this strategy may lead in the long-run to a high risk of HIV infection, because people may have several steady sexual partners through their life and be faithful in each one, but this will not protect the person against the illness as this may be picked up in any of these relations and from having unprotected sex on just one occasion.

As different authors (Castañeda, 2000; Cummings et al., 2006; Dias et al., 2005; Gavey \& McPhillips, 1999; Salgado de Snyder, Acevedo, Díaz-Pérez \& SaldívarGarduño, 2000; Sherman, Gielen \& McDonnell, 2000; Tschann, Adler, Millstein, Gurvey \& Ellen, 2002) have pointed out, it is possible that while young men may use or avoid using a condom without discussing it with their women sexual partner because condom use is under the physical control of men, for young women, condom use depends on their male partner's willingness and the desire to use a condom may be more complex and challenging, requiring assertive behavior that may violate gender role norms. For example, Tschann et al. (2002) have found that, although there is not a direct relation between gender and decision making over condom use, men perceive themselves as having more power and emotional influence than women in the framework of partner relations, power which is in turn related to imposing their point of view or desires in relation to the use or not of the condom. In turn, the results of several studies (Castañeda, 2000; Quina, Harlow, Morokoff, Burkholder \& Deiter, 2000) underline the association of women's skills of sexual communication for information about the partner's past HIV-risk behavior with the adoption of safe sex. It may also be true that the greater need of the woman to link sexuality and love in relations (Barrón, Martínez-Íñigo, de Paúl \& Yela, 1999; Hatfield, Sprecher, Pillemer, Greenberger \& Wexler, 1988; Kvalem \& Træen, 2000) may lead towards a certain abandonment of preventive aspects so as not to harm the romanticism of the relationship. These reasons may have a bearing on the fact that, as we found in the regression analyses conducted, for young men the condom use intention is sufficient to ensure implementation of this behavior, while for women the necessary negotiation skills are also required.

Less perceived self-efficacy compared to young men for buying condoms or knowing how to put them on correctly, data that has also been found by other researchers (Martínez-Donate et al., 2004), is another factor that could also have a bearing on the non-materialization of the attitudes and intentions of the women in our sample in more effective preventive behavior against HIV. On this point, several studies have found that women are less aware of how to use them correctly and feel more embarrassed about having to go and buy them (Meekers \& Klein, 2002).

We have seen that the gender differences found in our study are upheld in two samples of university students from two countries with different patterns of HIV transmission 
and different national prevention programmes, and they also coincide with those found by other researchers analysing young men and women from different social and cultural contexts. As a result of this, we believe that these differences must be taken into account when designing prevention programmes for adolescents and young adults in general and university students in particular. If they want to be effective, condom promotion programmes must address the characteristics and concerns of the population for which they are intended (Bazargan et al., 2000; Bimbela et al., 2002; Campbell et al., 1992; Fazecas et al., 2001; Gebhardt et al., 2003; Manuel, 2005; Meekers \& Klein, 2002). Because of this and agreeing with the abovementioned authors, we consider that these programmes must base themselves on the peculiar meanings that sentimental and sexual relations have for young adults and from this perspective try and promote a more healthy sexuality, making them aware of the dangers of the false sense of security that there is in monogamy and show them that they can combine the condom use with enjoyment of sexual relations and demonstrate to them the means by which the use of condoms may be incorporated into a satisfactory sexual life. And as women seem to put themselves in the most vulnerable position, the messages and programmes aimed at women should be designed primarily to increase self-efficacy in negotiation skills with the partner, helping them to assume an assertive role in the relation, but separating the condom use from the idea of coldness or lack of trust in the partner, transmitting instead the idea that the use of protective measures is a behavior that demonstrates maturity, responsibility, care of oneself but also of one's partner, which are very desirable qualities and values. But in addition to the negotiation skills, these programmes must give women the confidence to go and buy condoms themselves and use them correctly, if necessary with direct instruction on how to use them, as well as including messages to increase social acceptance and support from their significant contexts (parents, friends, teachers,...) to help young women adopt these behavior. Finally, another important preventive measure may be the promotion of female condom, in greater extension under the physical control of women than the male condom.

Although we believe that the contributions of this work can be very useful, we must acknowledge that it has certain limitations. We want to emphasize that, despite using an integrative model like the PBT, there are factors that are outside the model and that its inclusion would allow us to improve the predictive power of this. Moreover, as an anonymous reviewer suggested, an opportunity to improve this work is to perform some regression analysis not only by gender or country, but by the type of partner (stable / casual). It will be interesting to see how far this new variable may condition the explanatory power of the model, or explain the differences found between girls and boys, or even change the weight of the factors that explain the intention and the condom use.

\section{References}

Ajzen I. (1985). From intentions to actions: A theory of planned bahavior. In J Kuhl \& J. Beckmann (Eds.), Action Control: From cognition to behaviour (pp. 11-39). New York: SpringerVerlag.

Amaro, H., Raj, A., \& Reed, E. (2001). Women's sexual health: The need for feminist analyses in public health in the Decade of Behaviour. Psychology of Women Quarterly, 25, 324-334.

Babikian, T., Freier, M.C., Hopkins, G.L., DiClemente, R., McBride, D., \& Riggs, M. (2004). An assessment of HIV/AIDS risk in higher education students in Yerevan, Armenia. AIDS Behavior, $8,47-61$.

Baele, J., Dusseldorp, E., \& Maes, S. (2001). Condom use selfefficacy: Effect in intended and actual condom use in adolescents. Journal of Adolescent Health, 28, 421-431.

Barrón, A., Martínez-Íñigo, D., de Paúl, P., \& Yela, C. (1999). Romantic Beliefs and Myths in Spain. The Spanish Journal of Psychology, 2, 64-73

Basen-Engquist, K., Mâsse, L.C., Coyle, K., Kirby, D., Parcel, G.S., Banspach, S., \& Nodora, J. (1999). Validity of scales measuring the psychosocial determinants of HIV/STD-related risk behaviour in adolescents. Health Education Research, 14, 25-38.

Bayés, R., Pastells, S, \& Tuldra, A. (1995). Percepción del riesgo de transmisión del virus de inmunodeficiencia humana (VIH) en estudiantes universitarios. (Perception of risk of transmission of HIV in university students). Cuadernos de Medicina Psicosomática, 33, 22-27.

Bazargan, M., Kelly, E.M., Stein, J.A., Husaini, B.A., \& Bazargan, S.H. (2000). Correlates of HIV risk-taking behaviours among African-american college students: The effect of HIV knowledge, motivation, and behavioural skills. Journal of the National Medical Association, 92, 391-404.

Bimbela, J.L., Jiménez, J.M., Alfaro, N., Gutiérrez, P., \& March, J.C. (2002). Uso del profiláctico entre la juventud en sus relaciones de coito vaginal (Condom use among the young engaging in vaginal intercourse). Gaceta Sanitaria, 16, 298307.

Bosompra, K. (2001). Determinants of condom use intentions of university students in Ghana: An application of the theory of reasoned action. Social Science and Medicine, 52, 1057-1069.

Bradley, G., \& Wildman, K. (2002). Psychosocial predictors of emerging adults' risk and reckless behaviours, Journal of Youth and Adolescence, 31, 253-265.

Campbell, S.M., Peplau, L.A., \& DeBro, S.C. (1992). Women, men, and condoms: Attitudes and experiences of heterosexual college students. Psychology of Women Quarterly, 16, 273-288.

Carrasco, A., Muñoz-Silva, A., \& Sánchez-García, M. (2003). Conductas de prevención respecto a la transmisión sexual del SIDA en jóvenes y expectativas de autoeficacia: Un estudio en función del género (Prevention behavior as regards sexual transmission of AIDS in young people and self-efficacy expectations: A gender study). Revista de Psicología de la Salud, 15, 95-109. 
Castañeda, D. (2000). The close relationship context and HIV/AIDS risk reduction among Mexican Americans. Sex Roles, 42, 551580.

Cerqueira-Santos, E., Koller, S., \& Wilcox, B. (2008). Condom use, contraceptive methods, and religiosity among youths of low socioeconomic level. The Spanish Journal of Psychology, $11,94-102$.

Cok, F., Gray, L.A., \& Ersever, H. (2001). Turkish university students' sexual behaviour, knowledge, attitudes and perceptions of risk related to HIV/AIDS. Culture, Health \& Sexuality, 3, 81-99.

Comissão Nacional Luta Contra a Sida (2004). Plano Nacional de Luta Contra a Sida 2004-2006. (National Plan against AIDS 2004-2006). Available at: http://www.sida.pt/upload/ membro.id/ficheiros/i005526.pdf. Accessed on 12 September 2006.

Coordenação Nacional para a Infecção VIH/SIDA (2006). Protocolos celebrados. 2006. (Held actions. 2006). Available at: http://www.sida.pt/default.asp. Accessed on 2 September 2006.

Cummings, B., Mengistu, M., Negash, W., Bekele, A., \& Ghile, T. (2006). Barriers to and facilitators for female participation in an HIV prevention project in Rural Ethiopia: Findings from a qualitative evaluation. Culture, Health \& Sexuality, 8, 251-266.

Dekin B. (1996). Gender differences in HIV-related self-reported knowledge, attitudes, and behaviors among college students. American Journal of Preventive Medicine, 12, 61-66.

Dias, S.F., Matos, M.G., \& Gonçalves, AC. (2005). Preventing HIV transmission in adolescents: an analysis of the Portuguese data from the Health Behaviour School-aged Children study and focus group. European Journal of Public Health, 15, 300-304.

EuroHIV (2006). HIV/AIDS surveillance in Europe: mid-year report 2005, No 72. August. Saint-Maurice, Institut de Veille Sanitaire. Available at http://www.eurohiv.org. Accesed on 25 June 2008.

EuroHIV (2007). HIV/AIDS surveillance in Europe: end-year report 2006, No 75. Saint-Maurice, Institut de Veille Sanitaire. Available at http://www.eurohiv.org. Accesed on 25 June 2008.

Fazecas, A., Senn, Ch., \& Ledgerwood, D. (2001). Predictors of intention to use condoms among university women: An application and extension of the theory of planned behavior. Canadian Journal of Behavioral Science, 33, 103-117.

Gavey, N., \& McPhillips, K. (1999). Subject to romance. Heterosexual passivity as an obstacle to women initiating condom use. Psychology of Women Quarterly, 23, 349-367.

Gebhardt, W.A., Kuyper, L., \& Greunsven, G. (2003). Need for intimacy in relationships and motives for sex as determinants of adolescent condom use. Journal of Adolescent Health, 33, 154-164.

Gutiérrez, L., Oh, H.J., \& Gillmore, M.R. (2000). Toward an understanding of (em)power(ment) for HIV/AIDS prevention with adolescent women. Sex Roles, 42, 581-611.

Hatfield, E., Sprecher, S., Pillemer, J.T., Greenberger, D., \& Wexler, P. (1988). Gender differences in what is desired in the sexual relationship. Journal of Psychology and Human Sexuality, 1, $39-52$.
Holschneider, S.O.M., \& Alexander, C.S. (2003). Social and Psychological influences on HIV preventive behaviors of youth in Haiti. Journal of Adolescent Health, 33, 31-40.

Hynie, M., Lydon, J.E., Côté, S., \& Wiener, S. (1998). Relational sexual scripts and women's condom use: The importance of internalized norms. The Journal of Sex Research, 35, 370380 .

Instituto de Salud Carlos III \& Ministerio de Sanidad y Consumo. Vigilancia Epidemiológica del SIDA en España (2005). Registro Nacional de Casos de SIDA. Actualización a 31 de diciembre de 2005. (National AIDS cases Registry. Update on 31 December 2005). Available at: http://www.isciii.es/htdocs/pdf /informe_sida.pdf. Accessed on 2 September 2006.

Kotchick, B.A., Shaffer, A., Forehand, R., \& Miller, K.S. (2001). Adolescent sexual risk behavior: A multi-system perspective. Clinical Psychology Review, 21, 493-519.

Krahé, B., \& Reiss, C. (1995). Predicting intentions of AIDSpreventive behavior among adolescents. Journal of Applied Social Psychology, 25, 2118-2140

Kvalem, I.L., \& Træen, B. (2000). Self-efficacy, scripts of love and intention to use condoms among Norwegian adolescents. Journal of Youth and Adolescence, 29, 337-353.

Lameiras, M., Nuñez, A.M., Rodríguez, Y., Bretón, J. y Agudelo, D. (2005). Actividad sexual y uso del preservativo en jóvenes universitarios gallegos. (Sexual activity and male condom use by university students from Galicia). Clínica y Salud, 16(3), 253-267.

Laraque, D., Maclean, D.E., Brown-Peterside, P., Ashton, D., \& Diamond, B. (1997). Predictors of reported condom use in central Harlem youth as conceptualized by the Health Belief Model. Journal of Adolescent Health, 21, 318-327.

Manuel, S. (2005). Obstacles to condom use among secondary school students in Maputo city, Mozambique. Culture, Health \& Sexuality, 7, 293-302.

Martínez-Donate, A.P., Hovell, M.F., Blumberg, E.J., Zellner, J.A., Sipan, L., Shillington, A.M., \& Carrizosa, C. (2004). Gender differences in condom-related behaviors and attitudes among mexican adolescents living on the U.S.-Mexico border. AIDS Education and Prevention, 16, 172-186.

Meekers, D., \& Klein, M. (2002). Understanding gender differences in condom use self-efficacy among youth in urban Cameroon. AIDS Education and Prevention, 14, 62-72.

Merakou, K., Costopoulos, C., Marcopoulou, J., \& KoureaKremastinou, J. (2002). Knowledge, attitudes and behavior after 15 years of HIV/AIDS prevention in schools. European Journal of Public Health, 12, 90-93.

Ministério da Saude \& Instituto Nacional de Saúde Dr. Ricardo Jorge. Centro de Vigilância Epidemiológica das Doenças Transmissíveis (2006). Infecção VIH/SIDA. A situação em Portugal. 30 de Junho de 2006. Doc. 136. (HIV/AIDS Infection. The situation in Portugal. 30 June 2006). Available at: http://www.insarj.pt/site/resources/docs/SIDA_30_de_Junho_de_ 2006.pdf . Accessed on 2 September 2006.

Moore, S., Rosenthal, D., \& Mitchell, A. (1996). Youth, AIDS and sexually transmitted diseases. London: Routledge. 
Murphy, D.A., Rotheram-Borus, M.J., \& Reid, H.M. (1998). Adolescent gender differences in HIV-related sexual risk acts, social-cognitive factors and behavioral skills. Journal of Adolescence, 21, 197-208.

Newman, P.A., \& Zimmerman, M.A. (2000). Gender differences in HIV-related sexual risk behavior among urban African American youth: A multivariate approach. AIDS Education and Prevention, 12, 308-325.

Oliva, A., Serra, L., \& Vallejo, R. (1993). Sexualidad y anticoncepción en jóvenes andaluces. (Sexuality and contraception in Andalusian young people). Sevilla: Servicio Andaluz de Salud, Consejería de Salud.

Parsons, J.T., Halkitis, P.N., Bimbi, D., \& Borkowski, T. (2000). Perceptions of the benefits and costs associated with condom use and unprotect sex among late adolescent college students. Journal of Adolescence, 23, 377-391.

Quina, K., Harlow, L.L., Morokoff, P.J., Burkholder, G., \& Deiter, P.J. (2000). Sexual communication in relationships: When words speak louder than actions. Sex Roles, 42, 523-549.

Reinecke, J., Schmidt, P., \& Ajzen, I. (1996). Application of the theory of planned behavior to adolescents' condom use: a panel study. Journal of Applied Social Psychology, 26, 749-772.

Rosenstock, I.M., Strecher, V.J., \& Becker, M.H. (1994). The health belief model and HIV risk behavior change. In R.J. DiClemente \& J.L. Peterson (Eds.), Preventing AIDS: Theories and Methods of Behavioral Interventions (pp. 5-24). New York: Plenum Press.

Sacco, W.P., Rickman, R.L., Thompson, K., Levine, B., \& Reed, D.L. (1993). Gender differences in AIDS-relevant condom attitudes and condom use. AIDS Education and Prevention, 5, 311-326.

Salgado de Snyder, V.N., Acevedo, A., Díaz-Pérez, M.J., \& Saldívar-Garduño, A. (2000). Understanding the sexuality of Mexican-born women and their risk for HIV/AIDS. Psychology of Women Quarterly, 24, 100-109.

Sánchez-García, M. (2001). Validación de ítems y pruebas: una aplicación a la medición de conductas de riesgo de transmisión del VIH (Validation of items and tests: An application to the measurement of risk behaviors of HIV transmission). Doctoral thesis not published. Seville, University of Seville.

Secretaría del Plan nacional sobre el SIDA del Ministerio de Sanidad y Consumo (1997). Plan de Movilización Multisectorial frente al VIH/SIDA 1997-2000. (Multisectorial Action Plan against HIV/AIDS 1997-2000). Available at:
http://www.msc.es/ciudadanos/enfLesiones/enfTransmisibles/sida /planesEstrat/planMultisectorial.htm. Accessed on 12 September 2006.

Seidman, S.N., \& Rieder, R.O. (1994). A review of sexual behavior in the United States. American Journal of Psychiatry, 151, 330-341.

Sherman, S.G., Gielen, A.C., \& McDonnell, K.A. (2000). Power and attitudes in relationships (PAIR) among a sample of lowincome, African-American women: Implications for HIV/AIDS prevention. Sex Roles, 42, 283-294.

Siegel, D.M., Klein, D.I., \& Roghmann, K.J. (1999). Sexual behavior, contraception, and risk among college students. Journal of Adolescent Health, 25, 336-343.

Thorburn, S., Harvey, S.M., \& Ryan, E.A. (2005). HIV prevention heuristics and condom use among African-American at risks for HIV. AIDS Care, 17, 335-344.

Tschann, J.M., Adler, N.E., Millstein, S.G., Gurvey, J.E., \& Ellen, J.M (2002). Relative power between sexual partners and condom use among adolescents. Journal of Adolescent Health, $31,17-25$.

UNAIDS (2004). Report on the global AIDS epidemic. 2004. Available at: http://www.unaids.org. Accessed on 24 October 2005.

UNAIDS (2006). Report on the global AIDS epidemic. 2006. Available at: http://www.unaids.org/en/HIV_data/2006GlobalReport/ default.asp. Accessed on 2 September 2006.

UNAIDS \& WHO (2004). AIDS epidemic update: December 2004. Available at: http://www.unaids.org. Accessed on 24 October 2005.

UNAIDS \& WHO (2005). AIDS epidemic update. December 2005. Available at: http://www.unaids.org. Accessed on 15 March 2006.

UNAIDS \& WHO (2006). AIDS epidemic update : Special report on HIV/AIDS: December 2006. Available at: http://www.unaids.org. Accessed on 25 June 2008.

Wendt, S.J., \& Solomon, L.J. (1995). Barriers to condom use among heterosexual male and female college students. Journal of American College Health, 44, 105-110.

Woolf, S. E., \& Maisto, S. A. (2008). Gender differences in condom use behavior? The role of power and partner-type. Sex Roles, $58,689-701$.

Received February 5, 2008 Revision received October 26, 2008 Accepted October 30, 2008 